\title{
Study of Heritable Variable for Physiomorphic and Fruit Yield Traits in Brinjal (Solanum melongena L.)
}

\author{
Bhagwan Bamaniya*, S. S. Singh and Anita Parmar
}

Department of Crop Sciences, (Mahatma Gandhi Chitrakoot Gramodaya Vishvavidyalaya, Chitrakoot Satna (MP), India

*Corresponding author

Keywords

Phenotypic and genotypic coefficient of variation,

Heritability and genetic advance, Brinjal

Article Info

Accepted: 20 December 2020 Available Online: 10 January 2021
A field experiment was conducted during kharif, 2017 and 2018 at Horticulture Research Farm, Mahatma Gandhi Chitrakoot Gramodaya Vishvavidyalaya, Chitrakoot Satna (M.P). To study growth, yield parameters on twenty five germplasm/varieties of Brinjal. Design of experiment was RBD with three replications. In the present investigation that high phenotypic and genotypic coefficient of variation, High estimates of heritability coupled with high genetic advance as percentage of mean were recorded for plant height, fruit length, fruit width, number of fruits per plant and fruit yield per plant which indicated predominance of additive gene action which provide better scope for improvement of these traits through effective selection of genotype/varieties.

\section{Introduction}

Brinjal or eggplant having $2 \mathrm{n}$ chromosome number 24 belongs to family solanaceae, which is major commercial vegetable crop of the world (Kallu, 2002). Brinjal originated India and comprised very high diversity which classified as often cross pollinated crop (Choudhary 1976).

White skin brinjal is said to be good for diabetic patients and the de-cholestrolizing control is attributed to the presence of polyunsaturated fatty acids (linoleic and lenolenic) which are present in the flesh and seeds of the fruits $(65.1 \%)$. In addition, it is used as a good appetizer, good aphrodisiac, cardio tonic, laxative and reliever of inflammation. The egg plant is said to be the cheaper vegetable for poor class people. India is an agriculture based country in the world having $2.4 \%$ of the world's arable land with which to feed 15\% of world population to provide food for one billion people (Biswas et al., 2009). 
The efforts for enhancing production and productivity of vegetables play a major role in this regard. India is the second largest producer of vegetables after China (75 million tonnes) constituting $9.4 \%$ of the total production (Hegde et al., 2009). Majority of the Indians are vegetarian and per capita consumption is $135 \mathrm{~g}$ per day as against the recommended $300 \mathrm{~g}$ per day (Dhandapani et al., 2003). Therefore major attention, a lot of emphasis has been given to increase the production and productivity of major vegetable crops and its marketing throughout Indian around the year.

In India brinjal area 730.35 hundred hectare and production is 12860 hundred MT, while in Madhya Pradesh area is 51.35 and production 1073.63. (NHB, 2018).

The world human population is expected to become 8 billion by the end of 2030 Therefore, to overcome world hunger an emphasis must be given on enhancing vegetables production along with staple crops in Asia, Africa and Subtropical regions.

Morphological characterization and categorization is the basic step for classification of genetic stock collection for several characters of agronomic and physiological importance. The Collection of germplasm and assessment of genetic variability is a basic step in any crop improvement program. The fruit yield is being a complex character influenced by number of yield contributing characters which controlled by polygene's and also influenced by the environment, so the variability in the collections of concerned genes plus the influence of the environment, it becomes necessary to partition the observed variability into heritable and non-heritable components measured as genotypic and phenotypic coefficient of variation (GCV and PCV), heritability and genetic advance.
To develop high yielding variety for commercial cultivation needs basic high diversity in the genetic stock. Information on heritability together with genetic advance of fruit yield traits are essential, hence present investigation was undertaken to study heritable variation on 25 genotypes where it is in Brinjal.

\section{Materials and Methods}

The present investigation was carried out to access the genetic variation in brinjal. The field experiment was conducted at the Horticulture form Mahatma Gandhi Chitrakoot Gramodaya Vishwavidyalaya Chitrakoot Satna, during kharif 2017 and 2018. The experiment materials comprised 25 genotypes/ varieties grown in the randomised block design with three replications. five randomly selected plants were considered for recording different characters viz. plant height $(\mathrm{cm})$, number of leaves per plant, branches per plant, days to first flowering, days to $50 \%$ flowering, days to first picking, fruiting span, number of fruits per plant, fruit length $(\mathrm{cm})$, fruit width, fruit circumference (cm), fruit weight(g), and fruit yield per plant. The analysis of variance was computed for all characters (Panse and Sukhatme (1985) and PCV and GCV were calculated by Burton and De Vane (1952), while heritability and genetic advance was estimated as per formula given by Allard (1960).

\section{Results and Discussion}

Analysis of variance indicated that mean sum of square due to genotypes were found significantly for all characters and indicated presence of variability among the genotypes for fruit yield per plant and it's a contributing component. These findings are in close agreement with findings of Tripathi et al., (2009) and Ravali et al., (2017). Ansari et al., (2011) and Shede et al., (2015) and Patel et al., (2017). 
Table.1 Estimates of genetic parameters of variations for various characters in Brinjal in first year

\begin{tabular}{|c|c|c|c|c|c|c|c|c|c|c|c|}
\hline \multirow[t]{2}{*}{ Characters } & \multirow[t]{2}{*}{$\begin{array}{l}\text { Grand } \\
\text { Mean }\end{array}$} & \multicolumn{2}{|c|}{ Range } & \multicolumn{3}{|c|}{ Variances } & \multicolumn{2}{|c|}{$\begin{array}{c}\text { Coefficient of } \\
\text { variations }\end{array}$} & \multirow[t]{2}{*}{$\begin{array}{l}\text { Heritabili } \\
\text { ty \% (BS) }\end{array}$} & \multirow[t]{2}{*}{$\begin{array}{l}\text { Genetic } \\
\text { Advance }\end{array}$} & \multirow{2}{*}{$\begin{array}{c}\text { GA as } \\
\% \text { of } \\
\text { mean }\end{array}$} \\
\hline & & Min. & Max. & Pheno & Gen & Enviro & Pheno. & Geno. & & & \\
\hline Plant height $(\mathrm{cm})$ at 30DAT & 21.33 & 14.80 & 26.60 & 15.24 & 11.94 & 3.30 & 18.30 & 16.20 & 78.37 & 6.30 & 29.55 \\
\hline Plant height $(\mathrm{cm})$ at 60DAT & 55.22 & 43.60 & 72.73 & 141.82 & 123.52 & 18.30 & 21.57 & 20.13 & 87.10 & 21.37 & 38.69 \\
\hline Plant height $(\mathrm{cm})$ at 90DAT & 77.25 & 65.80 & 101.00 & 129.09 & 105.55 & 23.53 & 14.71 & 13.30 & 81.77 & 19.14 & 24.77 \\
\hline No. of leaves/plant at 30DAT & 8.38 & 6.33 & 11.27 & 2.18 & 1.25 & 0.93 & 17.63 & 13.36 & 57.41 & 1.75 & 20.84 \\
\hline No. of leaves/plant at 60DAT & 33.96 & 23.07 & 45.53 & 45.66 & 29.20 & 16.45 & 19.90 & 15.91 & 63.96 & 8.90 & 26.22 \\
\hline No. of leaves/plant at 90DAT & 36.78 & 28.13 & 49.27 & 59.48 & 34.11 & 25.37 & 20.97 & 15.88 & 57.35 & 9.11 & 24.77 \\
\hline No. of branches/plant at 30 DAT & 4.55 & 2.87 & 5.87 & 0.83 & 0.53 & 0.30 & 20.07 & 16.06 & 64.09 & 1.21 & 26.49 \\
\hline No. of branches/plant at 60DAT & 9.55 & 6.73 & 12.33 & 3.85 & 2.75 & 1.09 & 20.52 & 17.37 & 71.60 & 2.89 & 30.29 \\
\hline No. of branches/plant at 90DAT & 10.90 & 8.47 & 14.07 & 2.99 & 2.17 & 0.82 & 15.87 & 13.52 & 72.65 & 2.59 & 23.74 \\
\hline Days to first flowering & 42.12 & 39.07 & 44.93 & 3.84 & 2.31 & 1.53 & 4.66 & 3.61 & 60.17 & 2.43 & 5.77 \\
\hline Days to $50 \%$ flowering & 57.56 & 53.80 & 64.27 & 8.60 & 6.11 & 2.49 & 5.09 & 4.29 & 71.08 & 4.29 & 7.46 \\
\hline Days to first picking & 65.09 & 59.07 & 69.67 & 8.29 & 5.29 & 3.00 & 4.42 & 3.53 & 63.85 & 3.79 & 5.82 \\
\hline Fruiting span & 56.84 & 53.87 & 58.27 & 1.88 & 1.24 & 0.64 & 2.41 & 1.96 & 65.87 & 1.86 & 3.27 \\
\hline No. of fruits / plant & 13.75 & 8.53 & 18.80 & 7.41 & 6.23 & 1.18 & 19.80 & 18.15 & 84.02 & 4.71 & 34.27 \\
\hline Fruit length (cm) & 11.42 & 7.47 & 20.53 & 20.90 & 17.66 & 3.24 & 40.02 & 36.78 & 84.49 & 7.96 & 69.68 \\
\hline Fruit width (cm) & 5.31 & 4.07 & 7.27 & 0.93 & 0.73 & 0.20 & 18.17 & 16.08 & 78.32 & 1.56 & 29.33 \\
\hline Fruit circumference $(\mathrm{cm})$ & 16.68 & 12.77 & 22.82 & 8.88 & 7.35 & 1.53 & 17.86 & 16.26 & 82.82 & 5.08 & 30.48 \\
\hline Weight of fruit (g) & 149.41 & 117.33 & 182.33 & 203.20 & 181.37 & 21.83 & 9.54 & 9.01 & 89.26 & 26.21 & 17.54 \\
\hline Fruit yield / plant (kg) & 2.06 & 1.24 & 3.44 & 0.29 & 0.23 & 0.06 & 26.05 & 23.22 & 79.45 & 0.88 & 42.57 \\
\hline Fruit yield / plot (kg) & 4.15 & 3.26 & 5.06 & 0.17 & 0.14 & 0.03 & 9.80 & 8.86 & 81.73 & 0.68 & 16.50 \\
\hline Fruit yield / ha (q) & 461.14 & 362.14 & 562.76 & 204.70 & 167.38 & 373.20 & 9.81 & 8.87 & 81.77 & 76.21 & 16.53 \\
\hline
\end{tabular}


Table.2 Estimates of genetic parameters of variations for various characters in Brinjal in second year

\begin{tabular}{|c|c|c|c|c|c|c|c|c|c|c|c|}
\hline \multirow[t]{2}{*}{ Characters } & \multirow[t]{2}{*}{$\begin{array}{l}\text { Grand } \\
\text { Mean }\end{array}$} & \multicolumn{2}{|c|}{ Range } & \multirow{2}{*}{\begin{tabular}{|c|} 
Variances \\
Pheno \\
\end{tabular}} & \multirow[b]{2}{*}{ Gen } & \multirow[b]{2}{*}{ Enviro } & \multicolumn{2}{|c|}{$\begin{array}{c}\text { Coefficient of } \\
\text { variations }\end{array}$} & \multirow[t]{2}{*}{$\begin{array}{l}\text { Heritabilit } \\
\text { y \% (BS) }\end{array}$} & \multirow{2}{*}{$\begin{array}{c}\text { Genetic } \\
\text { Advanc } \\
\text { e }\end{array}$} & \multirow{2}{*}{$\begin{array}{c}\text { GA as } \\
\% \text { of } \\
\text { mean }\end{array}$} \\
\hline & & Min. & Max. & & & & Phenotypic & Genotypic & & & \\
\hline Plant height $(\mathrm{cm})$ at30 DAT & 20.83 & 15.53 & 26.27 & 10.09 & 8.35 & 1.74 & 15.26 & 13.88 & 82.76 & 5.42 & 26.00 \\
\hline Plant height $(\mathrm{cm})$ at 60DAT & 52.60 & 40.40 & 83.27 & 114.13 & 100.56 & 13.57 & 20.31 & 19.07 & 88.11 & 19.39 & 36.86 \\
\hline Plant height $(\mathrm{cm})$ at 90DAT & 82.26 & 69.20 & 107.87 & 104.88 & 86.07 & 18.81 & 12.45 & 11.28 & 82.07 & 17.31 & 21.05 \\
\hline No. of leaves/ plant at30 DAT & 9.30 & 7.07 & 11.47 & 2.62 & 1.48 & 1.13 & 17.41 & 13.11 & 56.68 & 1.89 & 20.32 \\
\hline No. of leaves/ plant at 60DAT & 38.23 & 28.73 & 48.60 & 34.17 & 26.90 & 7.28 & 15.29 & 13.56 & 78.70 & 9.48 & 24.79 \\
\hline No. of leaves/ plant at 90DAT & 42.35 & 34.80 & 55.40 & 54.22 & 32.35 & 21.87 & 17.39 & 13.43 & 59.66 & 9.05 & 21.37 \\
\hline $\begin{array}{c}\text { No. of branches/plant at30 } \\
\text { DAT }\end{array}$ & 4.58 & 3.47 & 5.73 & 0.53 & 0.35 & 0.18 & 15.84 & 12.91 & 66.37 & 0.99 & 21.67 \\
\hline $\begin{array}{c}\text { No. of branches/plant at } \\
\text { 60DAT }\end{array}$ & 10.74 & 8.13 & 15.53 & 4.79 & 4.09 & 0.70 & 20.38 & 18.84 & 85.43 & 3.85 & 35.85 \\
\hline $\begin{array}{l}\text { No. of branches/plant at } \\
\text { 90DAT }\end{array}$ & 13.01 & 9.47 & 19.33 & 5.06 & 3.76 & 1.30 & 17.29 & 14.90 & 74.31 & 3.72 & 28.63 \\
\hline Days to first flowering & 42.52 & 39.40 & 44.73 & 2.47 & 1.26 & 1.21 & 3.69 & 2.64 & 51.01 & 1.65 & 3.88 \\
\hline Days to $50 \%$ flowering & 57.54 & 53.27 & 63.73 & 8.50 & 5.89 & 2.62 & 5.07 & 4.22 & 69.23 & 4.16 & 7.23 \\
\hline Days to first picking & 64.83 & 60.53 & 69.13 & 6.04 & 2.62 & 3.42 & 3.79 & 2.49 & 43.35 & 2.19 & 3.39 \\
\hline Fruiting span & 56.03 & 53.60 & 58.33 & 1.34 & 1.09 & 0.25 & 2.06 & 1.86 & 81.50 & 1.94 & 3.46 \\
\hline No. of fruits / plant & 13.62 & 8.53 & 18.87 & 6.88 & 5.72 & 1.17 & 19.26 & 17.55 & 83.04 & 4.49 & 32.95 \\
\hline Fruit length (cm) & 11.51 & 7.67 & 20.47 & 19.95 & 17.61 & 2.34 & 38.80 & 36.45 & 88.26 & 8.12 & 70.56 \\
\hline Fruit width $(\mathrm{cm})$ & 5.34 & 4.13 & 7.27 & 1.04 & 0.76 & 0.28 & 19.07 & 16.29 & 73.00 & 1.53 & 28.66 \\
\hline Fruit circumference $(\mathrm{cm})$ & 16.76 & 12.98 & 22.82 & 9.35 & 7.88 & 1.47 & 18.25 & 16.75 & 84.23 & 5.31 & 31.67 \\
\hline Weight of fruit (g) & 149.11 & 117.33 & 171.33 & 151.08 & 133.55 & 17.52 & 8.24 & 7.75 & 88.40 & 22.38 & 15.01 \\
\hline Fruit yield / plant (g) & 2.03 & 1.24 & 3.07 & 0.24 & 0.21 & 0.02 & 23.90 & 22.72 & 90.35 & 0.90 & 44.58 \\
\hline Fruit yield / plot (kg) & 4.14 & 3.26 & 4.76 & 0.12 & 0.10 & 0.01 & 8.24 & 7.75 & 88.40 & 0.62 & 15.02 \\
\hline Fruit yield / ha (q) & 460.23 & 362.14 & 528.81 & 143.91 & 197.22 & 166.93 & 8.24 & 7.75 & 88.40 & 69.08 & 15.01 \\
\hline
\end{tabular}


Genotypic and phenotypic coefficient of variation

In the present findings, the values of phenotypic coefficient of variation were higher than genotypic coefficient of variation indicating effluence of environmental on the character expression. The high PCV as well as GCV was recorded for fruit length, fruit yield per plant, plant height, fruit width and number of fruits per plant it in both years, hence these traits are responsive for further improvement through selection. These findings are in close harmony with the results of Shirley and Santhi (2008), Divya and Sharma (2018), fruit yield and fruit length Ansari (2010) and Patel et al., (2017) and Muniappan (2017).

\section{Heritability and genetic advance}

In the present study, high heritability coupled with high genetic advance as per cottage of mean was recorded for traits namely plant at 60 DAT, fruit length, fruit yield per plant, number of branches suggested predominant of additive gene action and existence of sufficient heritable variation which provide wider scope for selection.

It can be concluded from the present investigation that high phenotypic and genotypic coefficient of variation, High estimates of heritability coupled with high genetic advance as percentage of mean were recorded for plant height, fruit length, fruit width, number of fruits per plant and fruit yield per plant which indicated predominance of additive gene action which provide better scope for improvement of these traits through effective selection of genotype/varieties.

\section{References}

Allard, R.W "Principles of plant Breeding "John Willey and Sons- New York
1960.

Ansari, S.F., Genetic analysis for earliness and heat tolerant along with yield attributing traits in Brinjal $\mathrm{PhD}$ thesis submitted to IG KVV Raipur (CG) 2010.

Burton, G.W., De Vane EH: Estimating heritability tall fescue (Festuca arundinacea) from replicated clonal material. Agron J. (1953): 45: 478-481.

Divya, Arti, Sharma, A.K. Genetic Variability variability studies for yield and quality parameters in Brinjal (solanum melongena L.) J. pharmocognosy (2018): 7: (5) 2094 -2496.

Kallu, G., Banergee, M.K., Singh,S.N., Singh, M.: Genetics of yield and its components characters in Brinjal (solanum melongena). Vegetable science 2002: 29: 24 -26.

Muniappan, S., savvanan, k Ramya, B, Studies on genetic divergence and variability for certain economic characters in eggplant (Solanum melongena L.) electronic J. Pl. Breed. 2010: I: (4):462 - 465.

Panse, PV, Sukhatme, PV. Statistical method for agricultural workers ICAR New Delhi 1985.

Patel, K., Patel, N.B.A.I., Rathod, H. and Patel, D.: Study of variability correlation and path analysis in Brinjal (solanum melongena L.). The bioscan 2015: (10) 2037 -2042 2042.

Ravti, B, Ravindra K.R., Saidaih, P., Shivraj, N. Variability heritability and genetic advance in Brinjal (solanum melongena). International Journal of current microbiology and Applied Sciences 2017 (6) 42-47.

Shide, K.G., Birajdar, U.M., bhalekar, M.N., Patel B.T.: Correlation and path analysis in eggplant (solanum melongena L.). Vegetable Sci. 2012: (39): $108-110$. 


\section{How to cite this article:}

Bhagwan Bamaniya, S. S. Singh and Anita Parmar. 2021. Study of Heritable Variable for Physiomorphic and Fruit Yield Traits in Brinjal (Solanum melongena L.). Int.J.Curr.Microbiol.App.Sci. 10(01): 3124-3129. doi: https://doi.org/10.20546/ijcmas.2021.1001.363 